\title{
COMMODITY EXPORTS, INVISIBLE EXPORTS AND TERMS OF TRADE FOR THE MIDDLE COLONIES, 1720 TO 1775
}

\author{
Peter Mancall \\ Joshua Rosenbloom \\ Thomas J. Weiss \\ Working Paper 14334 \\ http://www.nber.org/papers/w14334 \\ NATIONAL BUREAU OF ECONOMIC RESEARCH \\ 1050 Massachusetts Avenue \\ Cambridge, MA 02138 \\ September 2008
}

This paper was previously circulated with the title "The Role of Exports in the Economy of Colonial North America: New Estimates for the Middle Colonies". This research was funded in part by the National Science Foundation Grant SES-0317265. We thank participants in the DAE Summer Institute meetings, the 6th World Congress of Cliometrics, and the Western Washington University Department of Economics seminar for their comments on earlier versions of this paper. The views expressed herein are those of the author(s) and do not necessarily reflect the views of the National Bureau of Economic Research.

NBER working papers are circulated for discussion and comment purposes. They have not been peerreviewed or been subject to the review by the NBER Board of Directors that accompanies official NBER publications.

(C) 2008 by Peter Mancall, Joshua Rosenbloom, and Thomas J. Weiss. All rights reserved. Short sections of text, not to exceed two paragraphs, may be quoted without explicit permission provided that full credit, including $\odot$ notice, is given to the source. 
Commodity Exports, Invisible Exports and Terms of Trade for the Middle Colonies, 1720

to 1775

Peter Mancall, Joshua Rosenbloom, and Thomas J. Weiss

NBER Working Paper No. 14334

September 2008, Revised January 2010

JEL No. N11,N21,N7,N71

\title{
ABSTRACT
}

Economic historians of the eighteenth-century British mainland North American colonies have given considerable weight to the role of exports as a stimulus for economic growth. Yet their analyses have been handicapped by reliance on one or two time series to serve as indicators of broader changes rather than considering the export sector as a whole. Here we present new comprehensive export measures for the middle colonies. We find that aggregate exports in constant prices grew very quickly, but barely faster than population during the period under consideration. Furthermore, improvements in the terms of trade increased the colonists' ability to buy imports over time, especially after 1740. Although the export sector performed well, it constituted a relatively small part of the region's economy. It is uncertain if this export success was sufficient to propel the entire economy at a rate that exceeded the growth of population.

\author{
Peter Mancall \\ Department of History \\ University of Southern California \\ Los Angeles, CA 90089 \\ mancall@usc.edu \\ Joshua Rosenbloom \\ Department of Economics \\ University of Kansas \\ Snow Hall 436 \\ 1460 Jayhawk Blvd \\ Lawrence, KS 66045-2113 \\ and NBER \\ jrosenbloom@ku.edu
}

Thomas J. Weiss

University of Kansas

3128 Campfire $\mathrm{Ct}$

Lawrence, KS 66049

and NBER

t-weiss@ku.edu 
Most interpretations of colonial economic growth lean heavily on the performance of international exports. To some extent this comes out of necessity. "Almost the only data available for income estimates are hard external trade figures and estimates of population," Jacob Price noted. ${ }^{1}$ As a result, many scholars have stressed the causal role that exports have played as the primary engine of economic growth for the colonies. According to the dominant theme found in textbooks as well as scholarly works, enterprising Europeans arrived in North America and through hard work and abundant land created a prosperous and burgeoning economy based on the export of agricultural staples. $^{2}$ Such arguments emphasize that the growth of external demand for colonial exports was the crucial factor determining the pace of colonial economic growth. ${ }^{3}$ As Marc Egnal put it, even while acknowledging the limitations of the staple thesis, "the export of primary products was the engine of growth for the colonial economy... [and] the nature of these exports shaped the pattern of regional development."4

Yet for all the interpretive weight that others have placed on the export sector, our understanding of export performance in the colonial period remains relatively incomplete. With the exception of recent work on exports from the Lower South (Mancall, Rosenbloom and Weiss 2008), most scholars in the past have relied on an incomplete analysis of trade performance by focusing on the rates of growth of one or

\footnotetext{
${ }^{1}$ See Price (1984), 19.

${ }^{2}$ For example, Ratner, Soltow and Sylla (1993, p. 8) observed: "In the economy that evolved in the seventeenth and eighteenth centuries, staple commodities produced for export became the engine of growth as settlers capitalized on an abundance of resources and especially the fertility of the soil."

${ }^{3}$ See especially, McCusker and Menard (1984, p. 71); Shepherd and Walton (1972, pp. 20-21), and Egnal (1975, p. 199).

${ }^{4}$ Egnal (1998, pp. 4-5)
} 
two prominent commodities, colonial trade with only Great Britain, or other indicators of trading patterns, such as data on tonnage clearing various ports for specific sub-periods of time. ${ }^{5}$ They have not looked at the total value of colonial trade with the rest of the world. As a consequence, and not too surprisingly, different scholars looking at only portions of the export sector have arrived at noticeably divergent conclusions about the external trade of the Middle Colonies. ${ }^{6}$ As we elaborate below, the lack of a comprehensive and continuous measure of the export sector's performance has contributed to these disparate accounts of the timing of export growth and its impact on the region's economy. Although most scholars seem to accept that exports influenced the region's development, they do not agree on whether this resulted in a sluggish, modest or robust rate of economic growth. This divergence of opinion reflects in part the incompleteness of the evidence each scholar used. Until now, no one has combined the available evidence for New York and Pennsylvania to produce an export series for the region that covers the entire eighteenth century. ${ }^{7}$

In this paper we present new and more comprehensive measures of the overseas export performance for the Middle Colonies (New York, New Jersey, Pennsylvania, and Delaware). To produce these measures we have combined the available data for the

5 See for example, Arthur Jensen (1963, p. 50), James Lydon, (1967, p. 401), Marc Egnal (1998, pp. 49 and 63) and John J. McCusker and Russell R. Menard (1984, pp. 193-97).

${ }^{6}$ See for example, McCusker and Menard (1984, p. 204) compared to Egnal, 1998, p.47.

7 Most of these data are summarized in John McCusker's recent compilation of colonial trade statistics in Historical Statistics of the United States (2006), although McCusker chose not to include the data on tonnage compiled by Lydon (1967) from reports in several Philadelphia newspapers for 1720 to 1739. Egnal (1998, pp. 47-67), has made extensive use of these data, but his evidence pertains to the Northern colonies, not only the Middle Colonies, and its coverage is not consistent over time. For example, his discussion uses data on tonnage clearing Philadelphia for the entire period 1720-1774 but adds data on tonnage clearing New York, Boston and Salem in the years 1763-1774. And, as far as we can tell, he did not weight the tonnage from the various ports to reflect differences in the value of their cargoes. 
major exporting colonies in the region to estimate total and per capita export volumes at benchmark dates from c. 1726 to c. 1772; an annual series of regional exports based on interpolation between these benchmark dates and reaching back to 1720; and a series on invisible earnings. ${ }^{8}$ We also examine the impact of changes in the terms of trade to assess whether the real volume of exports was able to support an increasing volume of imports over time.

This paper is about trade, offering new export series and a new picture of the pace and timing of the Middle Colonies' external trade over the entire colonial period, as well as documenting important shifts in the source of regional exports. We show that aggregate commodity exports from the Middle Colonies grew rapidly, increasing nearly 6-fold in real value between 1720 and the early 1770s. There was also a significant shift in the sources of regional exports. In the 1720s New York exported more than Pennsylvania, but their positions eventually reversed. ${ }^{9}$ Over the entire period, Pennsylvania's exports rose ten-fold, while New York's increased a little more than three-fold.

Although this paper is not about economic growth, these new data have obvious implications for the region's economic performance. The region's commodity exports increased substantially, but their growth was not much faster than the growth of the region's population, which increased by a factor of 5.7 over the same period. As a result, the value of commodity exports per capita exhibited little trend before the American

\footnotetext{
8 Our series, described more fully in an appendix to this paper, encompass the period from 1720 to 1800 , but the discussion in this paper is confined to the colonial period, because the estimates for the post-Revolutionary War period are based on different sources and a different methodology.

9 An interesting question is whether the expansion of the port of Philadelphia facilitated the growth of exports or the growth of exports spurred the expansion of Philadelphia.
} 
Revolution. Such a finding is somewhat at odds with the notion, central to the staples thesis, that the expansion of foreign demand for staples products shaped colonial economic growth. We do not dispute the importance of exports as a source of foreign earnings that enabled colonists to afford imported luxuries and manufactured goods that they could not produce themselves. And it may still be the case that forward and backward linkages played a role in the development of increasingly sophisticated colonial economic institutions. But if the region's economic growth depended only on the growth of commodity exports per capita, its success would have been limited.

Taking account of earnings generated by invisible exports and adjusting for changes in the terms of trade helps to reconcile the perception of economic progress with the absence of change in the volume of commodity exports. The addition of invisible earnings raises the level of exports and exports per capita, and may have given a slight boost to growth. The terms of trade have a more noticeable impact. Although our constant price series of commodity exports per person rose only slightly between 1720 and 1770, improvements in the region's terms of trade meant that the volume of imports per capita that could be purchased by the region's population increased at a rate of over 1 percent per year. But a focus on longer-run trends obscures another important aspect of regional export performance. Regional exports were subject to very substantial short run fluctuations - rising and falling by as much as 70 percent within 3 to 5 years in each colony. These large changes must have added a great deal of uncertainty to the colonists' economic situation. 


\section{Exports of the Middle Colonies}

Virtually all of the quantitative evidence necessary to estimate commodity exports of the thirteen mainland British colonies can be found in data collected by imperial officials. During the eighteenth century naval officers in American ports compiled quarterly reports of all ships clearing and entering colonial ports along with details of the cargos they carried and their destinations. While a large number of these naval officers' lists have been preserved, their coverage for most ports is spotty and incomplete. ${ }^{10}$

British customs inspectors compiled a different, albeit similar, record of all arrivals in English and Welsh ports beginning in 1696 and Scottish ports beginning in 1740. These data, compiled at the time into annual ledgers listing the value of imports arriving from and exports leaving for different trading areas, provide a convenient timeseries of colonial exports to Britain. ${ }^{11}$ They do not, however, provide evidence about colonial exports to other areas, a limitation which is especially important for analyzing the trade of the Middle Colonies, whose merchants sent only a small fraction of their exports to British ports. The extent of this limitation is clear in data collected in the American Inspector General's Ledgers for 1768-1772. These records, compiled by the American Board of Customs, recorded the quantities of all commodities legally exported from and imported into 42 colonial port districts throughout the British North American mainland from January 5, 1768 through January 5, $1772 .^{12}$

\footnotetext{
${ }^{10}$ McCusker (2006) and Price (1984) provide good introductions to these data.

11 The compilers of these ledgers used a set of official values that reflected prices near the beginning of the eighteenth century. As a result these series are best interpreted as fixed-price indexes of the volume of trade (McCusker 2006, pp. 641-43).

${ }^{12}$ According to Shepherd and Walton (1972, p. 204) they "represent the only period for which we have data that purport to be a complete coverage of colonial overseas trade."
} 
Although the Middle Colonies' exports were less valuable than such southern staples as tobacco, rice and indigo, the region's fertile soil and abundant annual rainfall supported a productive agricultural sector that generated surpluses for export that have figured prominently in discussion about the region's economy. ${ }^{13}$ Residents of the Middle Colonies produced and exported a diverse array of products, but grain production, as the assistant secretary of Treasury for the newly founded United States Tench Coxe recognized during the post-Revolutionary era, dominated the region's exports. At the end of the colonial period bread and flour together with wheat made up nearly two-thirds of the value of regional exports, but Indian corn, flaxseed, and beef and pork also made a noticeable contribution to regional exports (see Appendix Table 2). In addition to agricultural products the region also exported modest amounts of manufactures, including pig and bar iron as well as a variety of wood products, such as staves, headings and shingles. Together this small group of products accounted for close to 90 percent of all exports from New York and Pennsylvania.

New York and Pennsylvania dominated exports from the Middle Colonies in these years, together accounting for more than 96 percent of the value of regional exports (see Appendix Table 1). But most of these exports were not bound for Great Britain. Instead, more than three quarters of the region's exports went either to the West Indies or

\footnotetext{
${ }^{13}$ Despite a wealth of material on the Middle Colonies there has been no comprehensive overview of the region's economic history. A number of studies have explored aspects of Philadelphia's trading relationships, but less work has been done on New York. Despite some recent studies of New York, discussions of the extent and growth of regional trade remain sketchy and impressionistic. McCusker and Menard (1984, pp. 191-93) cited a number of studies that traced the history of trade through Philadelphia, but reported that the literature on New York's trade was distinctly more limited, concluding that Harrington (1935) remained the best work on the subject of New York's trade. A somewhat more recent addition to the literature is Matson (1998).
} 
Southern Europe. As a result, the volume of exports from New York and Pennsylvania to Britain provides an imperfect and distorted guide to the importance of trade in the region. Unfortunately, it is impossible to find quantitative estimates as comprehensive for earlier years. A number of scholars have been able to piece together data on the quantities of exports of specific commodities from Philadelphia for scattered years, but these data are too sparse and inconsistent to allow a reconstruction of the volume of trade earlier in the century. ${ }^{14}$ As a result, most of the analysis of trading patterns of the region's major ports has relied on information on the tonnage of ships clearing for different destinations, which are available for a greater number of years. ${ }^{15}$ The tonnage data illustrate both the rapid growth in the volume of trade from the region and the shifting importance of different trading regions. We have used these data to compile a more complete time series of the region's trade which captures the impact of the shifting importance of New York and Philadelphia and of the various destinations for their exports. ${ }^{16}$

\footnotetext{
${ }^{14}$ Helen Klopfer (1936) assembled data on exports of wheat, flour, bread, and corn for most years after 1760, but before that she was able to obtain only scattered observations for a few years. Lydon (1967) reports data for a few years in the early 1730s, but these are not entirely consistent with those found in Klopfer's work. Shepherd and Williamson (1972, p. 170) summarized what can be gleaned about exports of bread and flour from New York from the Naval Officers lists analyzed by Louis Harper. Their tables indicate that with the exception of data for 1733-1735, there are only a few scattered years with usable data. There are no data in this source for Philadelphia, as the records from this port appear to have been destroyed at some point in the nineteenth century.

15 See in particular, Jensen (1962), Lydon (1967), McCusker and Menard (1984), Egnal (1998). In Appendix Tables 5 and 6 we report tonnage clearing Philadelphia and New York in all of the years for which we could find data.

16 Tonnage clearing for other mainland colonies also increased over time. Although coastal shipments were part of the region's overall trade, they were not part of the foreign trade we are focusing on here. We have estimated that the value of the region's trade with other mainland colonies was in the range of approximately $\$ 1$ to $\$ 2$ per capita from the early 1700 s through the end of the colonial period, and displayed little or no trend growth.
} 


\section{New Estimates of Exports from the Middle Colonies, 1700-1772}

Our estimates of the region's commodity exports begin with the tonnage data that have been used by other scholars but we develop a framework within which the tonnage data may be used to derive estimates of the value of regional exports. Following this methodology we have constructed two sets of estimates of the region's exports for the years from 1700 to 1772: a series of benchmark estimates at dates for which tonnage data are available for both New York and Pennsylvania, and a second series that interpolates between these benchmark figures to produce an annual series. ${ }^{17}$ The benchmark data establish the trends in exports over the long term and major sub-periods, while the interpolated series provides plausible annual values for other years, and thus reveals growth over time periods that differ from those circumscribed by the benchmark years.

The details of our estimation procedure along with the underlying data are described in the Appendix. Here we briefly summarize the major steps in the process. To convert the data on tonnage clearing colonial ports into export volumes we used data from the American Inspector-General's ledger tabulated by Shepherd (1969) to establish the average annual quantities of commodity exports in the years 1768-1772 from New York and Philadelphia to each of five destination regions. Then we converted these quantity figures into a monetary value using 1840 prices and calculated the value per ton clearing each port for each destination by dividing the value of exports by the average annual tonnage clearing. ${ }^{18}$ For all destinations except Great Britain we multiplied the

\footnotetext{
${ }^{17}$ For each of the two colonies, we also have a benchmark series that differs in terms of the time period covered and has additional benchmark dates than those found in our regional benchmark series.

${ }^{18}$ Because our eventual goal is to integrate these export figures with estimates of regional income, and to link these eighteenth century income figures to those for the nineteenth century,
} 
time series data on tonnage by our base period estimates of value per ton to estimate the value of exports from each colony. ${ }^{19}$ To estimate exports to Great Britain we extrapolated the base year value of exports using an index derived from the constant value series of imports into Great Britain from each colony. After aggregating the value of exports to each destination from New York and Pennsylvania we inflated them to capture the value of the region's exports from Delaware and New Jersey.

Table 1 presents the base year data (1768-72) on the value of exports in 1840 prices, tonnage clearing for various destinations, and the average value per ton to each destination from New York and Philadelphia. In both regions, the value per ton clearing for Southern Europe was the highest of any destination, and by a fairly wide margin, especially for Philadelphia, where the average value shipped to Southern Europe (\$88.87) was 42 percent higher than that for the West Indies, the second highest value-per-ton destination. For exports to all destinations, the value per ton clearing Philadelphia was approximately 13 percent higher than that for New York, a difference of about $\$ 8$ per ton. Shifts in the importance of New York and Philadelphia as ports of origin, and in the destinations of the exports from each port, had bearing on the growth of the region's export trade.

we valued regional exports in 1840 prices, reported by Cole (1938). Because the relative prices of different commodities affect their weight in the overall calculation, shifts in relative prices could have an impact on the size of regional exports. In practice, however, relative commodity prices in 1840 were highly correlated with those in the 1770s, so the choice of base year prices has little impact on our estimates. See the Appendix, especially Table 3.

19 The assumption that the ratio of cargo values to tonnage remained constant over the period from 1720 through 1772, appears reasonable based on data for the years when tonnage and the value of imports into Britain (in constant Sterling value) are both available. As shown in the Appendix, those data indicate that, if anything, the value per ton fell slightly over time. If this were true for other destinations then our assumption of constant value per ton imparts an upward bias to our estimates of the growth of exports over the period 1720-1772. 
Changes in the relative importance of the various destinations were more pronounced for New York's trade than Philadelphia's. In Table 2 we present the average shares of tonnage clearing each of these ports by destinations for the sub-periods of time for which we have benchmark data. For the most part, the relative importance of destinations did not increase or decrease steadily or on a long term basis, but rather rose and fell during various subperiods of time. Only the West Indies share of New York's trade declined throughout the period from 72 percent in the 1720 s to 43 percent in 1768 72. For Philadelphia, the share rose slightly between the 1720 s and 1754 , and then declined. Despite these different patterns over time, trade with the West Indies comprised approximately the same average share of each port's exports for the entire period 1720 to 1770 . Another noticeable shift was the rise in the importance of Britain's share of New York's trade, especially after mid-century, which meant an increase in tonnage clearing that carried - on average - less valuable exports than ships clearing for any other destination except Africa. The only other shift of any consequence was the rise in the importance of Ireland's share of the trade of both New York and Philadelphia. For New York, this represented a rise in the importance of a destination for which the average value per ton cleared was higher than that for the destination declining in relative importance, namely the West Indies. For Philadelphia, the effect is less obvious since the rise of Ireland's share came at the expense of shipments to both Britain, where value per ton was lower, and the West Indies, where it was higher. Moreover, for Philadelphia the rise in Ireland's importance took place in the 1720s and 1730s, relatively early in the period. 
The net impact of the shifting importance of destinations for each port is shown in Figures 1A and 1B. There we present a comparison of the behavior of the unweighted tonnage data with our value-weighted series (the benchmark estimates of exports) between 1726 and 1772. The differences between the series are not large, but in both cases, the weighted value index rises more slowly than the unweighted tonnage series. The differences in growth between the two indices are roughly the same for each of the colonies. And, for both New York and Philadelphia, the slower growth of the weighted series reflects the declining importance of the West Indian market, for which the value per ton was higher than for other regions.

The timing and pace of growth in the region's exports reflects both the shifting importance of the various destinations, as well as the changing importance of Philadelphia vis-à-vis New York. In Figure 1C, we show the weighted and unweighted series for New York and Philadelphia combined. Although we have fewer observations - because the number of years for which we have reported tonnage figures for both colonial ports is fewer than the number of years for which we have tonnage figures for at least one of them - the pattern is the same. The weighted series rises slightly more slowly than the unweighted series. Between 1726-27 and 1768-72, the unweighted index rose 350 percent, whereas the weighted tonnage index increased by only 340 percent.

\section{Growth between Benchmark Dates}

Table 3 presents the rates of growth between the various benchmark dates, and over longer periods of time. For the combined series, tonnage clearing rose faster than the value of exports in three of the five intervals, and perhaps more importantly did so 
over periods of time cumulating to 34.5 years while the export series outpaced tonnage for only 10 years. Over the entire period, the two series grew at very similar rates, with the tonnage series having increased slightly faster at 3.47 percent versus 3.43 percent per year. Again, the ports had different experiences. For New York, the tonnage series had the edge in the same time periods as in the combined series, but the differences were larger in almost every period. For Philadelphia, the export series increased more rapidly in three of the time periods, although the tonnage series increased more rapidly over the longer periods of time, totaling 27 years versus 17.5 for the export series. Over the entire period, $1726-27$ to $1770-72$, the tonnage series grew faster than the export series in New York (2.66 percent vs. 2.46) whereas the rates of growth were nearly identical in the case of Philadelphia.

Whichever of the two series one considers, the growth of exports from Philadelphia was quite rapid, whereas exports from New York did not fare so well. Taken together, exports from these two colonies combined nevertheless grew at a notable pace over the entire period 1726-1772, and in every sub-period that we are able to distinguish with the existing evidence. Based on the benchmark estimates, growth of the region's exports over the long term averaged 3.44 percent per year. In only one time period (1750-54 to 1765-67) did the rate fall below 3.0 percent, while in two sub-periods it exceeded 4.0 percent, and in the brief period 1733-35 to 1739 it exceeded 5.0 percent.

Of course, the region's population was also growing rapidly--3.57 percent per year for New York and Pennsylvania combined. As a consequence, the value of commodity exports per capita for Pennsylvania and New York combined was unchanged between the benchmark date of 1726-27 and in 1770-72 (see Table 4). Over this same 
period export values per capita fell for New York and increased slightly for Pennsylvania. Despite the relative long-run stability, export values rose and fell by more than one dollar per capita, between some of the benchmark dates.

Although the differences in growth between the unweighted (tonnage) and weighted (export value) series are not large, a comparison of the combined value of exports with that for individual colonies shows how previous scholars have come to different conclusions regarding the region's trade. McCusker and Menard argued that the export sector was doing well after 1720, recovering from an earlier slump, and “...Philadelphia’s external commerce, however measured, nearly tripled in size between 1720 and 1740." ${ }^{20}$ McCusker and Menard did not make clear the basis for this conclusion about the growth in Philadelphia's trade, but apparently it was based on tonnage clearing that port, which rose from 2,847 tons in $1720-22$ to 8,107 in $1737-39 .{ }^{21}$ Marc Egnal, on the other hand, offered a pessimistic assessment of the region's economic fortunes in the first half of the eighteenth century. "Lackluster sales of flour, bread, and other exports [before 1745]," he argued, "slowed northern growth. At the heart of the problem was the downturn in the British West Indies." ${ }^{22}$ The tonnage data, as just noted, do not support this. ${ }^{23}$ While tonnage clearing Philadelphia for the West Indies did not keep pace with the buoyant trade described by McCusker and Menard, it nevertheless

\footnotetext{
${ }^{20}$ McCusker and Menard (1984, p. 204).

21 The tripling is more obvious if one looks at the individual terminal year values which were 2,980 tons in 1720 and 9,050 in 1739.

${ }^{22}$ Egnal, 1998, pp. 47. Egnal did not report on the Middle Colonies separately, but rather on the broader Northern region, which included New England.

${ }^{23}$ It seems his conclusion may be based on the behavior of flour exports per capita from Pennsylvania. (Egnal, 1998, p.51, Figure 4.5). His conclusion implies that much of the increased tonnage clearing Philadelphia was sailing empty.
} 
doubled between 1726-27 and 1737-39. ${ }^{24}$ Moreover, tonnage clearing for Southern

Europe rose nearly six-fold, while tonnage clearing for Ireland rose from nothing to 1,450

tons, an increase which by itself increased total tonnage clearing Philadelphia by about 50

percent. On the other hand, if Egnal had also taken New York's exports into account his gloomy picture of trade would have been close to the truth. Tonnage clearing New York rose by only 40 percent between $1726-27$ and $1739 .{ }^{25}$ Tonnage clearing from the two ports combined rose by about 55 percent between 1726-27 and 1739, an increase more like that described by Egnal than the booming trade depicted by McCusker and Menard.

\section{Annual Series of Exports from the Middle Colonies}

We used these benchmark figures to construct an annual series of exports for the region by interpolation. ${ }^{26}$ To create this series we first interpolated the tonnage series from each colony to each destination, except Great Britain, between benchmark dates and then weighted those tonnage figures by the value per ton in the base years of 1768-72. For exports to Great Britain we extrapolated the base year value of exports by changes in the official values of imports into Great Britain from each colony, which are available in every year. To obtain the regional total value of commodity exports in each year we summed the values clearing for each destination from New York and Philadelphia, and inflated this sum to account for exports from New Jersey and Delaware, on the

\footnotetext{
${ }^{24}$ For a slightly longer period, $1720-22$ to $1737-39$, using 3 year averages, tonnage cleared from Philadelphia nearly tripled rising by 185 percent. Tonnage cleared in 1720 was higher than in any of the three succeeding years, so from that single year to 1739 tonnage clearing for the West Indies rose by only 57 percent.

25 Between 1715 and 1739 tonnage clearing New York rose by only 20 percent.

26 The resulting series is in Appendix Table 15 and the per capita figures derived from this series are plotted in Figure 2.
} 
assumption that the share of regional exports from these two colonies was constant and equal to its value in the base years, which was approximately 3.5 percent.

This series involves more construction than the benchmark series, and may not capture all the ups and downs in international trade, but nevertheless it does provide a rough gauge of the region's fortunes over sub-periods of time that do not necessarily coincide with the periodization established by the benchmark dates. Further, the annual estimates allow us to extend the series back to 1720 , thereby covering more of the colonial period than was possible with the benchmark evidence. This series yields results which, if nothing else, indicate how sensitive the estimated rates of growth are to changes in the beginning date of coverage, and to the methods of estimation.

This annual series shows lower average values of exports per capita and different rates of growth than does the benchmark series over comparable time periods. The lower average values simply reflect the inclusion of Delaware and New Jersey, each of which exported far less than either New York or Pennsylvania. Their inclusion raises population considerably but increases exports by less than five percent. Whereas the benchmark series indicated no change in the value of exports per capita from New York and Pennsylvania between 1726-27 and 1770-72 (See Table 4), the annual series shows a slight rise of 0.04 percent per year over that same period. The reason for this is that population in Delaware and New Jersey was growing more slowly than in New York and Pennsylvania, while our method of estimation assumed that exports from Delaware and New Jersey grew at the same rate as those from New York and Pennsylvania. ${ }^{27}$ Thus the

\footnotetext{
${ }^{27}$ We added a constant percentage of exports to capture those for Delaware and New Jersey and thus implicitly assumed that the growth rate of the exports for the region would not change.
} 
inclusion of these two colonies slows down the rate of growth of the region's population, but not the growth of its exports.

Moreover, the annual series yield higher rates of growth for Pennsylvania and the region over the entire period--if the series begins in 1720 rather than 1726-27. For Pennsylvania, the rate of growth was 0.70 beginning in 1720 versus only 0.13 beginning in 1726-27. For the entire region, the rate of growth beginning in 1720 was 0.31 , whereas it was only 0.04 from 1726-27 forward. ${ }^{28}$ New York's performance on the other hand appears worse; the rate of growth was -0.30 between $1726-27$ and 1770-72 using the benchmark series, but declined at -0.53 using the annual series that begins in $1720-22$.

As an example of the different sub-periods of time that can be examined with the annual series, but not the benchmark series, consider the changes in the region's trade over the period 1720 to 1745 , rather than $1726-27$ to 1739 as dictated by the benchmark dates. $^{29}$ The benchmark series indicated that exports from New York and Pennsylvania rose by 4.32 percent per year between $1726-27$ and 1739 and exports per capita rose at a rate of 0.24 percent per year. The annual series shows that for the period 1720 to 1745 exports rose by 3.84 percent annually, and on a per capita basis the value increased at only 0.13 percent per year.

\section{Invisible Service Exports}

In addition to the visible trade in commodities, the American colonies also produced a number of invisible service exports. These included earnings from goods

\footnotetext{
28 These rates were all calculated from end points. A natural log regression estimate for the region shows a rate of 0.22 percent per year.

29 The period 1720 to 1745 is that identified by Egnal as one of relatively slow growth.
} 
carried on colonial owned ships as well as charges for other commercial services such as insurance and commissions. The estimates constructed by Shepherd and Walton (1969) for 1768-1772 indicate that income from shipping and commercial services in foreign trade from the Middle Colonies was worth nearly 44 percent of the value of the region's commodity exports. ${ }^{30}$ These earnings may have been increasing over time, as suggested by the traditional story about the rising importance of colonial merchants in trans-Atlantic trade. One proxy for the growing role of colonial merchants is provided by data on the share of tonnage owned by residents of the colonies. McCusker (1972) found that local ownership increased relatively rapidly, but data in Crowther (1973), and Walton (1968) suggest that the rate of growth of colonial ownership may have been slower than implied by McCusker's data.

Because invisible exports were so substantial their value must be estimated throughout the century in order to have a better gauge of the overall level of foreign trade. The value of these services, which were largely earnings from shipping, was closely linked to the value of the trade in commodities, so would rise and fall reflecting the volume of exports. The other factor that would affect the value of these service exports was change in the share of these earnings that accrued to the colonists in the region, which to a large extent can be taken into account by changes in the ownership of tonnage engaged in trade. As described in the Appendix, we used the evidence on the relative importance of invisible exports for 1768-72, along with our new series on commodity exports and an estimate of changes in ownership of registered tonnage, to

${ }^{30}$ Invisible earnings were highest in the trade with Great Britain and Ireland, where they reached nearly 50 percent of the value of commodity exports, and lowest in the trade with Southern Europe and the Wine Islands, where they amounted to 34 percent of the value of visible trade. 
construct a time series on invisible exports. We assumed that the ratio of invisible to visible exports to each destination was the same for both New York and Philadelphia and equal to the regional value implied by Shepherd and Walton's estimates for the end of the colonial period (i.e. 1768-1772), and multiplied these ratios by our estimates of commodity exports from these two colonies by destination to construct an unadjusted series of invisible earnings in each year. We then adjusted these figures to reflect the changes in ownership over time. We assumed that the proportion of this income earned by residents of the Middle Colonies varied in proportion to the share of tonnage owned in the region and that the ownership share increased at a rate of 0.4 percent per year between 1720 and $1772 .^{31}$ We then summed these destination-specific estimates for New York and Philadelphia, and inflated them, as we did for the value of visible exports, to produce estimates for the region as a whole. Although the resulting series on invisible earnings may not be as reliable as that for commodity exports, it nonetheless improves the overall level of earnings the Middle Colonies received from the foreign trade sector, and captures the growing role of colonial merchants in trans-Atlantic trade. Table 4 reveals our estimates of this broader measure of trade on a per capita basis, where it can be compared to the figures for commodity trade, and Figure 2 shows the relationship between exports and population by graphing the per capita values of commodity exports and of the combined value of commodity and invisible service exports. This figure reveals that per capita exports varied widely around a gradually increasing trend. Per

31 See the appendix for a discussion of the evidence underlying the assumption about growth in ownership. The 0.4 percent per year is the mid-point between no growth as implied by the data for 1715-43 to 1763-65 presented by Shepherd and Walton (1969, Table 3) and the growth of 0.83 percent per year shown in McCusker's data for 1726-29 to 1770-75 (1972, Table 3). Estimates based on the work of Crowther (1973, Table 8) and Walton (1968, Tables 3 to 7) fall in that range. 
capita values of commodity exports in the first third of the period fluctuated between about $\$ 4.50$ and $\$ 5.50$ and then rose to a colonial era peak around $\$ 6.00$ in 1750 before beginning a sustained decline that lasted until the conclusion of the Seven Years' War. From the mid-1760s through the early 1770 s per capita export values recovered, rising to nearly $\$ 6$ per capita toward the end of the colonial period. Accounting for invisible earnings raises the level of exports by about $\$ 2$ per capita in any year, but does not dramatically change the trend in the series or alter the pattern of year-to-year fluctuations. $^{32}$

Even with invisible earnings included, the export sector constituted a relatively small component of the regional economy. We do not have regional per capita income estimates for the Middle Colonies, but Mancall and Weiss (1999, p. 26) have estimated that per capita incomes for all colonies was around \$64 in 1700 and $\$ 68$ in 1770 (both years valued in 1840 prices), the latter figure being nearly identical to McCusker's estimate of $\$ 63$ for $1774 .{ }^{33}$ It is unlikely that the Middle Colonies deviated much from this average performance, so regional commodity exports ran between 8 and 10 percent of income. ${ }^{34}$ With invisible exports included, the value of the region's foreign trade amounted to 11 to 14 percent of income.

\section{Terms of Trade}

32 The trend based on regression estimates indicates that invisible earnings raise the growth of per capita exports slightly as shown in Figure 2, whereas when calculated from end points growth is reduced slightly as shown in Table 4.

33 McCusker's figure is reported in Susan Carter, et al, 2006, p. 5-671, Series Eg221.

${ }^{34}$ If we use McCusker's estimate that real GDP per capita was only 46 dollars in 1720 (Susan Carter, et al, 2006, p. 5-671, Series Eg221), than commodity exports amounted to between 10 and 14 percent of GDP per capita. 
So far our discussion has concentrated on the real value of exports. By abstracting from the effects of price changes we are able to identify changes in regional productivity that are the source of rising living standards. But prices matter. Changes in the terms of trade--shifts in the relative prices of exports to imports--are another avenue through which regional trade may have affected regional economic activity.

Over most of this period, British prices were quite stable, so changes in the terms of trade came about largely from fluctuations in the prices of the Middle Colonies' exports. Those prices fluctuated without any clear trend between 1720 and 1740 and then began to rise at a fairly robust rate around 2.0 percent per year. Over the entire period 1720 to 1770 the terms of trade improved on average at an annual rate of 1.04 percent. $^{35}$ The impact of these movements on regional terms of trade is shown in Figure 3, where we plot the ratio of a weighted index of prices of major regional exports to the Schumpeter-Gilboy price index, which represents movements of prices in Great Britain, the primary source of the region's imports.

The effect of these movements in relative prices was to exaggerate the decline in export values between the benchmark dates 1726-27 and 1739, and then magnify the later rise. Between 1726-27 and 1739 visible and invisible exports per capita fell at a rate of 0.48 per cent per year, while the terms of trade adjusted series fell at a rate of 2.6 percent per year (see Table 4). Over the long term, however, the effect of changes in the terms of trade was to enhance the growth in the purchasing power of the region's exports. Over the entire period from 1726-27 to 1772, exports per capita adjusted for the terms of trade

35 The prices of the region's exports fell from 1700 to 1720 and the terms of trade had deteriorated at 3.3 percent per year prior to 1720 . The rise after 1745 was so strong that the terms of trade recovered all of the ground lost from 1700 to 1720 by the time of the American Revolution. 
increased at a rate of almost 1 percent per year, while real exports per capita remained essentially constant.

\section{Conclusions}

Colonial economic historians have given considerable weight to the role of exports as a stimulus for economic growth. In part this reflects the pragmatic fact that exports are one of the few areas of the colonial economy for which reasonably sound and extensive quantitative data are available. Yet efforts to make use of these data have been handicapped by the incompleteness of the evidence. Scholars have tended to focus on the behavior of one or two key commodities, taking them as indicators of broader changes without placing them in the context of the export sector as a whole or comparing them to changes in the overall scale of the colonial economy.

Evidence for the Middle Colonies presented here reveals that commodity exports did grow quickly, and while this growth exceeded the pace of population growth, the difference was very small. While the trend rate of increase of per capita exports valued in constant prices was small the series fluctuated substantially, with the result that rates of growth are extremely sensitive to the choice of time period considered. Between the benchmark dates of 1726-27 and 1770-72 real commodity exports per capita increased at a rate of only 0.04 per cent per year, but annual data suggest that between 1720-22 and 1770-72 the rate of growth was 0.31 per cent per year. Invisible exports were a large component of colonial earnings, but the addition of this component does not dramatically alter the picture of relatively slow per capita export growth. The lack of long-run growth 
in the real value of exports suggests that there was little change in productivity between the 1720 s and 1770 s.

When changes in the terms of trade are taken into account, however, the growing value of regional exports meant that a constant volume of exports per capita allowed the region to purchase more imports. Thus, despite the lack of evidence of productivity advance, it appears that living standards may have been rising. The value of exports per capita adjusted for terms of trade rose at 1.6 percent per year between 1720 and 1770, with most of that increase having taken place after 1740 .

Our estimates also reveal something about the short-run performance of the regional economy. Even though our method of interpolation introduces an excessive degree of stability into the annual export series, our estimates nonetheless reveal a considerable degree of volatility, which suggests that that exports were not likely a constant fraction of GDP. It also suggests that the fortunes of the colonists waxed and waned, and an individual's view of the period would be influenced by how these fluctuations affected him or her.

Compiling all of the available data in a consistent framework helps to resolve the conflicting interpretations of the history of the Middle Colonies. Specifically, export growth continued at roughly the same pace throughout the entire period from 1720 to 1772, although changes in the terms of trade gave a boost to the value of exports after 1740. The stability in the unadjusted export series, however, masks the different records of slow-growing New York and rapidly increasing Philadelphia, which came to dominate regional exports. 
Viewed from the perspective of the export staples model of growth that is at the heart of most interpretations of colonial history these estimates suggest that the colonial economy may have been growing at a pace that compared well to what the U.S. experienced in the nineteenth century. In the simplest version of those models, where exports remain a constant percentage of the economy, real GDP per capita would have been rising at the rates at which exports were growing. Of course, other factors influenced the growth of GDP, and, as we have seen, the value of exports per capita from the Middle Colonies was a relatively small share of average incomes. In light of the large share of domestic production in the region's aggregate economic activity, it may be premature to use the performance of the export sector to extrapolate trends in overall performance. $^{36}$

\footnotetext{
${ }^{36}$ It may also be worthwhile to reexamine the idea that Malthusian forces rather than exports were the most important determinants of long run economic success in the mainland colonies. See Smith (1980) for further discussion of the merits of the Malthusian perspective. Even McCusker and Menard (1984) who place much more emphasis on the staple export model, acknowledge the relevance of Malthusian forces (chap.1). See also Edwin J. Perkins (1988, pp. $39-44)$
} 
Table 1

Average Annual Value of Exports from Philadelphia and New York by Destination, 1768-1772

\begin{tabular}{|c|c|c|c|c|c|}
\hline & \multicolumn{3}{|c|}{ U.S dollars, valued in prices of 1840} & \multirow[b]{2}{*}{$\begin{array}{c}\text { Average } \\
\text { Annual } \\
\text { Tonnage } \\
\text { Clearing } \\
\text { Port }\end{array}$} & \multirow[b]{2}{*}{$\begin{array}{l}\text { Value per } \\
\text { Ton } \\
\text { Clearing } \\
\end{array}$} \\
\hline & $\begin{array}{c}\text { Value of } \\
\text { Specified } \\
\text { Commodities }\end{array}$ & $\begin{array}{l}\text { Ratio of Total } \\
\text { Exports to } \\
\text { Specified } \\
\text { Commodities }\end{array}$ & $\begin{array}{l}\text { Value of All } \\
\text { Commodity } \\
\text { Exports }\end{array}$ & & \\
\hline \multicolumn{6}{|c|}{ From Philadelphia to: } \\
\hline Great Britain & $\$ 100,775$ & 1.49 & $\$ 150,205$ & 3,547 & $\$ 42.34$ \\
\hline Ireland & $\$ 161,659$ & 1.03 & $\$ 166,509$ & 3,481 & $\$ 47.84$ \\
\hline So. Europe & $\$ 808,523$ & 1.01 & $\$ 813,343$ & 9,152 & $\$ 88.87$ \\
\hline West Indies & $\$ 794,807$ & 1.06 & $\$ 839,316$ & 13,423 & $\$ 62.53$ \\
\hline Africa & $\$ 1,187$ & 1.00 & $\$ 1,187$ & 28 & $\$ 42.39$ \\
\hline Total & $\$ 1,866,951$ & & $\$ 1,970,561$ & 29,631 & $\$ 66.50$ \\
\hline \multicolumn{6}{|c|}{ From New York to: } \\
\hline Great Britain & $\$ 194,060$ & 1.19 & $\$ 231,417$ & 4,572 & $\$ 50.62$ \\
\hline Ireland & $\$ 151,346$ & 1.04 & $\$ 157,399$ & 2,363 & $\$ 66.61$ \\
\hline So. Europe & $\$ 184,201$ & 1.07 & $\$ 196,633$ & 2,607 & $\$ 75.42$ \\
\hline West Indies & $\$ 355,632$ & 1.15 & $\$ 407,357$ & 7,267 & $\$ 56.05$ \\
\hline Africa & $\$ 3,011$ & 1.00 & $\$ 3,011$ & 143 & $\$ 21.11$ \\
\hline Total & $\$ 888,249$ & & $\$ 995,816$ & 16,952 & $\$ 58.74$ \\
\hline
\end{tabular}

Source: Appendix Table 4. The specified items of export are bread and flour, beef and pork, flaxseed, Indian corn, wheat, bar iron, pig iron, potash, staves and American rum. See Appendix Table 2 for the details. 
Table 2

Shares of Tonnage Clearing for Various Destinations by Selected Time Periods

\begin{tabular}{|c|c|c|c|c|c|c|c|c|c|c|}
\hline & \multicolumn{5}{|c|}{ Clearing from to New York to } & \multicolumn{5}{|c|}{ Clearing from to Philadelphia to } \\
\hline & $\begin{array}{l}\text { Great } \\
\text { Britain }\end{array}$ & Ireland & $\begin{array}{l}\text { Southern } \\
\text { Europe }\end{array}$ & $\begin{array}{l}\text { West } \\
\text { Indies }\end{array}$ & Africa & $\begin{array}{c}\text { Great } \\
\text { Britain }\end{array}$ & Ireland & $\begin{array}{c}\text { S. } \\
\text { Europe }\end{array}$ & $\begin{array}{l}\text { West } \\
\text { Indies }\end{array}$ & Africa \\
\hline $1720 \mathrm{~s}$ & 0.19 & 0.00 & 0.09 & 0.72 & 0.00 & 0.19 & 0.01 & 0.16 & 0.64 & 0.00 \\
\hline $1730 \mathrm{~s}$ & 0.14 & 0.06 & 0.12 & 0.67 & 0.00 & 0.13 & 0.13 & 0.24 & 0.50 & 0.00 \\
\hline $1750 / 54$ & 0.19 & 0.15 & 0.07 & 0.59 & 0.01 & 0.06 & 0.14 & 0.10 & 0.70 & 0.00 \\
\hline $1763-67$ & 0.27 & 0.05 & 0.14 & 0.53 & 0.00 & 0.20 & 0.06 & 0.19 & 0.54 & 0.00 \\
\hline $1768-72$ & 0.27 & 0.14 & 0.15 & 0.43 & 0.01 & 0.12 & 0.12 & 0.31 & 0.45 & 0.00 \\
\hline $1720-72$ & 0.23 & 0.08 & 0.13 & 0.56 & 0.00 & 0.15 & 0.08 & 0.22 & 0.55 & 0.00 \\
\hline
\end{tabular}

Source: Philadelphia 1720-1739 from Lydon (1967); New York data and data for all other years in New York McCusker (2006, series Eg 514-553; Eg 554-593). 
Table 3

Comparison of Tonnage Clearing for Foreign Destinations and Benchmark Estimates of Exports

\begin{tabular}{|c|c|c|c|c|c|c|}
\hline & \multicolumn{2}{|c|}{$\begin{array}{l}\text { New York and } \\
\text { Philadelphia } \\
\text { Combined }\end{array}$} & \multicolumn{2}{|c|}{ New York } & \multicolumn{2}{|c|}{ Philadelphia } \\
\hline & $\begin{array}{l}\text { Tonnage } \\
\text { Clearing }\end{array}$ & $\begin{array}{c}\text { Benchmark } \\
\text { Estimates } \\
\text { of Exports }\end{array}$ & $\begin{array}{l}\text { Tonnage } \\
\text { Clearing }\end{array}$ & $\begin{array}{l}\text { Benchmark } \\
\text { Estimates } \\
\text { of Exports }\end{array}$ & $\begin{array}{l}\text { Tonnage } \\
\text { Clearing }\end{array}$ & $\begin{array}{c}\text { Benchmark } \\
\text { Estimates } \\
\text { of Exports }\end{array}$ \\
\hline & \multicolumn{6}{|c|}{ Two or Three Year Average Values (except 1739) } \\
\hline $1726-27$ & 10,408 & 673,314 & 5,388 & 344,950 & 5,020 & 328,364 \\
\hline $1733-35$ & 13,199 & 844,442 & 4,722 & 276,181 & 8,477 & 568,260 \\
\hline 1739 & 16,136 & $1,090,876$ & 7,086 & 435,828 & 9,050 & 655,047 \\
\hline $1750-54$ & 29,089 & $1,796,078$ & 11,041 & 630,488 & 18,048 & $1,165,591$ \\
\hline $1765-67$ & 40,605 & $2,456,593$ & 15,820 & 837,011 & 24,785 & $1,619,581$ \\
\hline $1770-72$ & 47,558 & $3,023,791$ & 17,304 & $1,018,336$ & 30,254 & $2,005,456$ \\
\hline & \multicolumn{6}{|c|}{ Average Annual Rates of Change Between Each Benchmark Periods } \\
\hline $1726-27$ to $1733-35$ & 3.22 & 3.07 & -1.74 & -2.92 & 7.23 & 7.59 \\
\hline $1733-35$ to 1739 & 4.10 & 5.25 & 8.46 & 9.55 & 1.32 & 2.88 \\
\hline 1739 to $1750-54$ & 4.64 & 3.91 & 3.00 & 2.49 & 6.48 & 5.38 \\
\hline $1750-54$ to $1765-67$ & 2.82 & 2.64 & 3.04 & 2.39 & 2.00 & 2.08 \\
\hline $1765-67$ to $1770-72$ & 3.21 & 4.24 & 1.81 & 4.00 & 4.07 & 4.37 \\
\hline & \multicolumn{6}{|c|}{ Average Annual Rates of Change between Longer Benchmark Periods } \\
\hline $1726-27$ to 1739 & 3.57 & 3.94 & 2.22 & 1.89 & 4.83 & 5.68 \\
\hline $1726-27$ to $1750-54$ & 4.11 & 3.92 & 2.64 & 2.22 & 5.85 & 5.79 \\
\hline $1733-35$ to $1750-54$ & 4.49 & 4.28 & 4.34 & 4.21 & 4.84 & 4.59 \\
\hline 1739 to $1765-67$ & 3.48 & 3.05 & 3.02 & 2.45 & 3.80 & 3.41 \\
\hline $1726-27$ to $1770-72$ & 3.47 & 3.43 & 2.66 & 2.46 & 4.12 & 4.15 \\
\hline & \multicolumn{6}{|c|}{ Other Periods Available for only one of the two colonies } \\
\hline 1715 to $1726-27$ & NA & NA & -0.82 & 0.34 & NA & NA \\
\hline $1720-22$ to $1726-27$ & NA & NA & NA & NA & 10.86 & 10.89 \\
\hline 1715 to 1739 & NA & NA & 0.75 & 1.14 & NA & NA \\
\hline $1720-22$ to 1739 & NA & NA & NA & NA & 6.64 & 7.09 \\
\hline $1720-22$ to $1737-39$ & NA & NA & NA & NA & 6.35 & 6.65 \\
\hline
\end{tabular}

Source: See Table 2 for sources of the tonnage data. The benchmark figures were calculated from the data in Appendix Table 15.

Notes: For 1750-54, we have combined the 1750 figure for New York with the 1754 figure for Philadelphia. In calculating growth rates, the terminal date is taken as 1752 for the combined series; 1750 for New York, and 1754 for Philadelphia. 
Table 4

Per Capita Value of Exports and Rates of Growth

\begin{tabular}{|c|c|c|c|c|c|c|}
\hline & \multicolumn{3}{|c|}{$\begin{array}{l}\text { Benchmark Values of Commodity } \\
\text { Exports Only }\end{array}$} & \multicolumn{3}{|c|}{$\begin{array}{l}\text { Annual Series for the Middle } \\
\text { Colonies }\end{array}$} \\
\hline & \multirow[b]{2}{*}{ New York } & \multirow[b]{2}{*}{ Pennsylvania } & \multirow[b]{2}{*}{$\begin{array}{c}\text { New York } \\
\text { and } \\
\text { Pennsylvania }\end{array}$} & $\begin{array}{l}\text { Commodity } \\
\text { Exports }\end{array}$ & \multicolumn{2}{|c|}{$\begin{array}{c}\text { Commodity Exports plus } \\
\text { Invisible Earnings }\end{array}$} \\
\hline & & & & \multicolumn{2}{|c|}{$\begin{array}{l}\text { without terms of trade } \\
\text { adjustment }\end{array}$} & $\begin{array}{c}\text { with } \\
\text { adjustment } \\
\text { for terms of } \\
\text { trade } \\
\end{array}$ \\
\hline & \multicolumn{6}{|c|}{ Two or Three Year Average Values (except 1739) } \\
\hline $1720-22$ & 7.89 & 5.73 & 6.88 & 4.71 & 6.46 & 3.58 \\
\hline $1726-27$ & 7.81 & 7.66 & 7.73 & 5.39 & 7.37 & 5.20 \\
\hline $1733-35$ & 5.10 & 8.98 & 7.19 & 5.07 & 6.77 & 4.74 \\
\hline 1739 & 7.03 & 8.04 & 7.61 & 5.34 & 6.94 & 3.74 \\
\hline $1750-54$ & 6.94 & 9.74 & 8.43 & 5.95 & 8.51 & 7.63 \\
\hline $1765-67$ & 5.86 & 7.50 & 6.84 & 5.09 & 7.02 & 6.60 \\
\hline $1770-72$ & 6.10 & 8.11 & 7.30 & 5.49 & 7.42 & 8.04 \\
\hline \multicolumn{7}{|c|}{ Average Annual Rates of Change Between Each Benchmark Periods } \\
\hline $1726-27$ to $1733-35$ & -5.52 & 2.14 & -0.96 & -0.82 & -1.12 & -1.20 \\
\hline $1733-35$ to 1739 & 6.63 & -2.18 & 1.13 & 1.05 & 0.49 & -4.65 \\
\hline 1739 to $1750-54$ & -0.09 & 1.75 & 0.79 & 0.83 & 1.58 & 5.64 \\
\hline $1750 / 1754$ to $1765-67$ & -1.40 & -1.62 & -1.48 & -1.11 & -1.37 & -1.03 \\
\hline $1765-67$ to $1770-72$ & 0.81 & 1.59 & 1.30 & 1.54 & 1.12 & 4.01 \\
\hline & \multicolumn{6}{|c|}{ Average Annual Rates of Change between Longer Benchmark Periods } \\
\hline $1726-27$ to 1739 & -0.84 & 0.39 & -0.13 & -0.08 & -0.48 & -2.60 \\
\hline $1726-27$ to $1750-54$ & -0.51 & 1.05 & 0.33 & 0.38 & 0.55 & 1.49 \\
\hline $1733-35$ to $1750-54$ & 1.55 & 0.51 & 0.89 & 0.89 & 1.28 & 2.68 \\
\hline 1739 to $1765-67$ & -0.68 & -0.26 & -0.39 & -0.18 & 0.04 & 2.13 \\
\hline $1726-27$ to $1770-72$ & -0.56 & 0.13 & -0.13 & 0.04 & 0.01 & 0.99 \\
\hline $\begin{array}{l}1720-22 \text { to } 1770-72 \\
\text { (interpolated series }\end{array}$ & -0.51 & 0.70 & 0.12 & 0.31 & 0.28 & 1.63 \\
\hline
\end{tabular}

Source: Appendix Table 15. 
Figure 1:

Comparison of Weighted and Unweighted Tonnage Series for New York and Philadelphia at Benchmark Dates

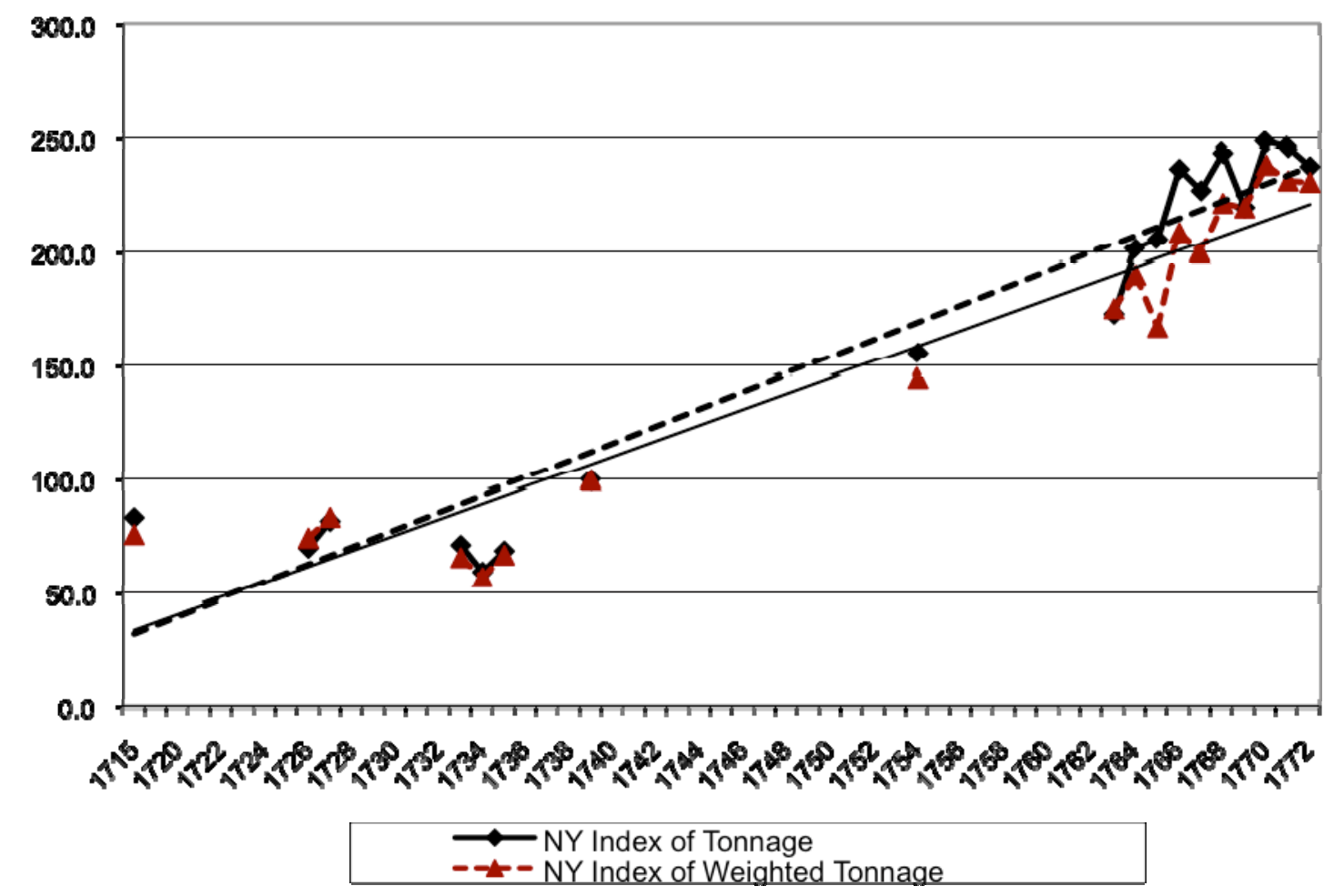

(a) Index of Tonnage Clearing New York at Benchmark Dates between 1715 and $1772(1739=100)$ 


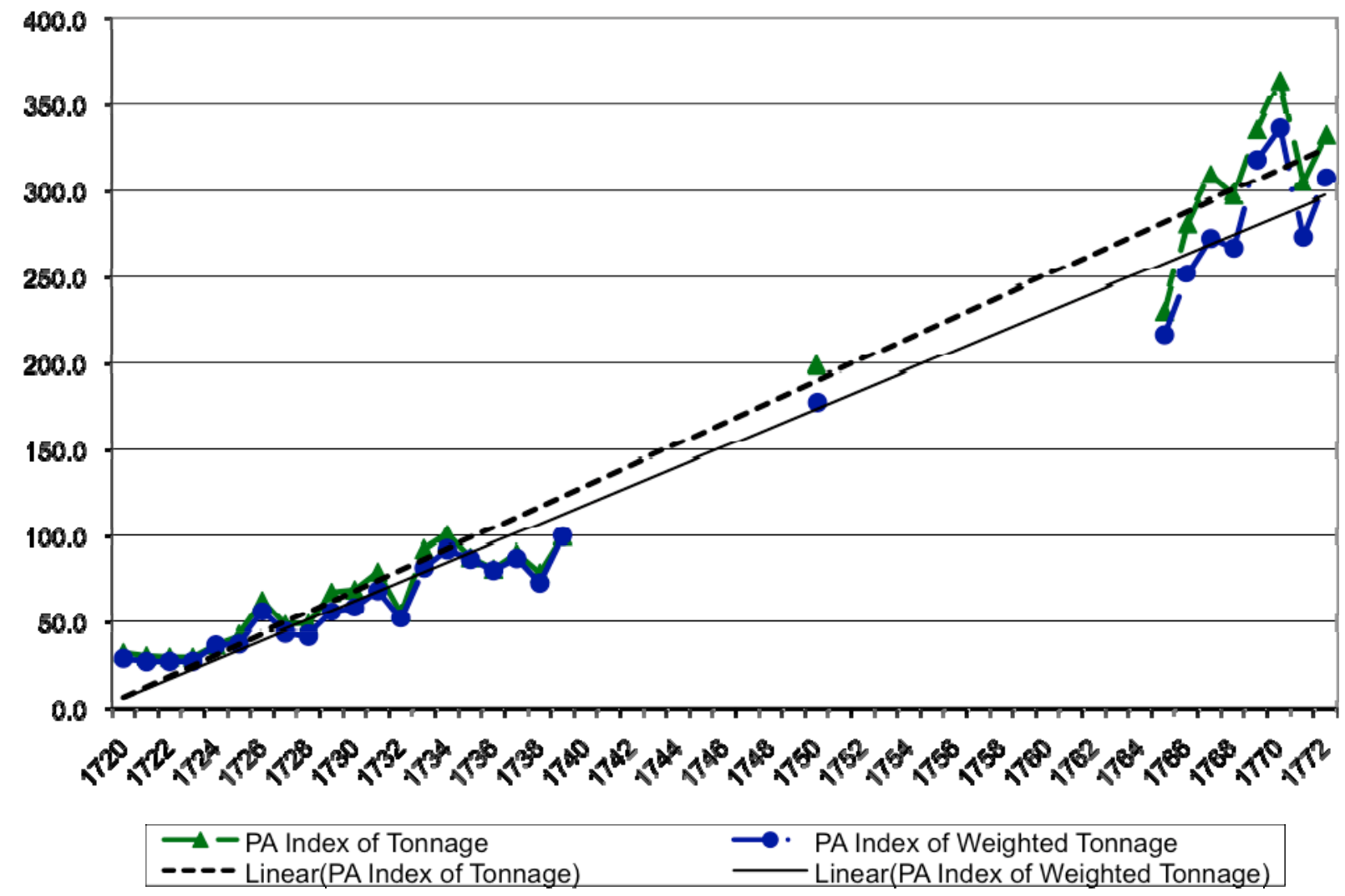

(b) Index of Tonnage Clearing Philadelphia at Benchmark Dates between 1720 and 1772 (1739=100) 


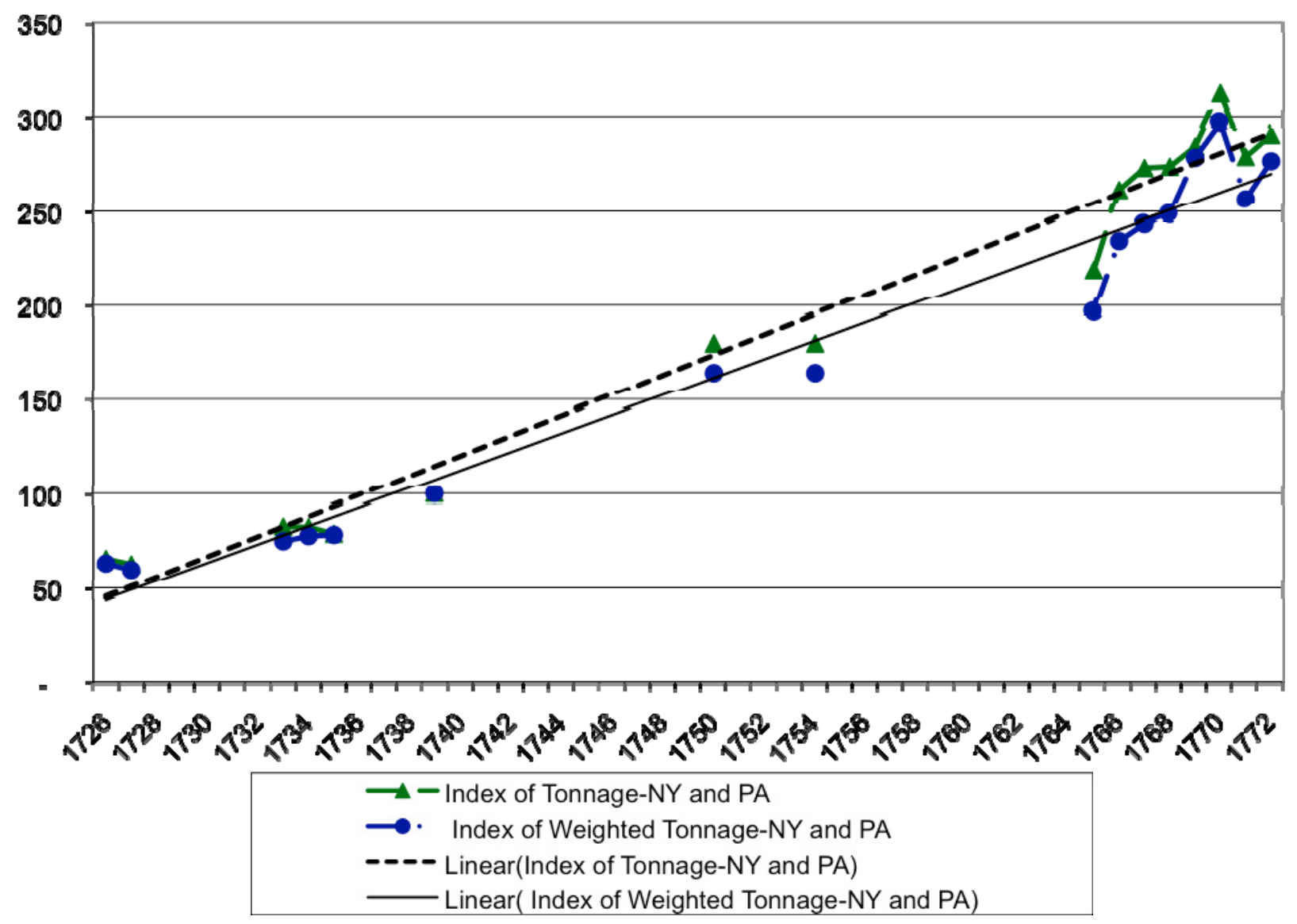

(c) Index of Tonnage Clearing New York and Philadelphia at Benchmark Dates between 1726 and 1772 (1739=100)

Notes and Sources: Based on authors' calculations as described in the text and the Appendix. 
Figure 2

Per Capita Exports from Middle Colonies

Commodities and Commodities plus Invisible Earnings, 1720-1772

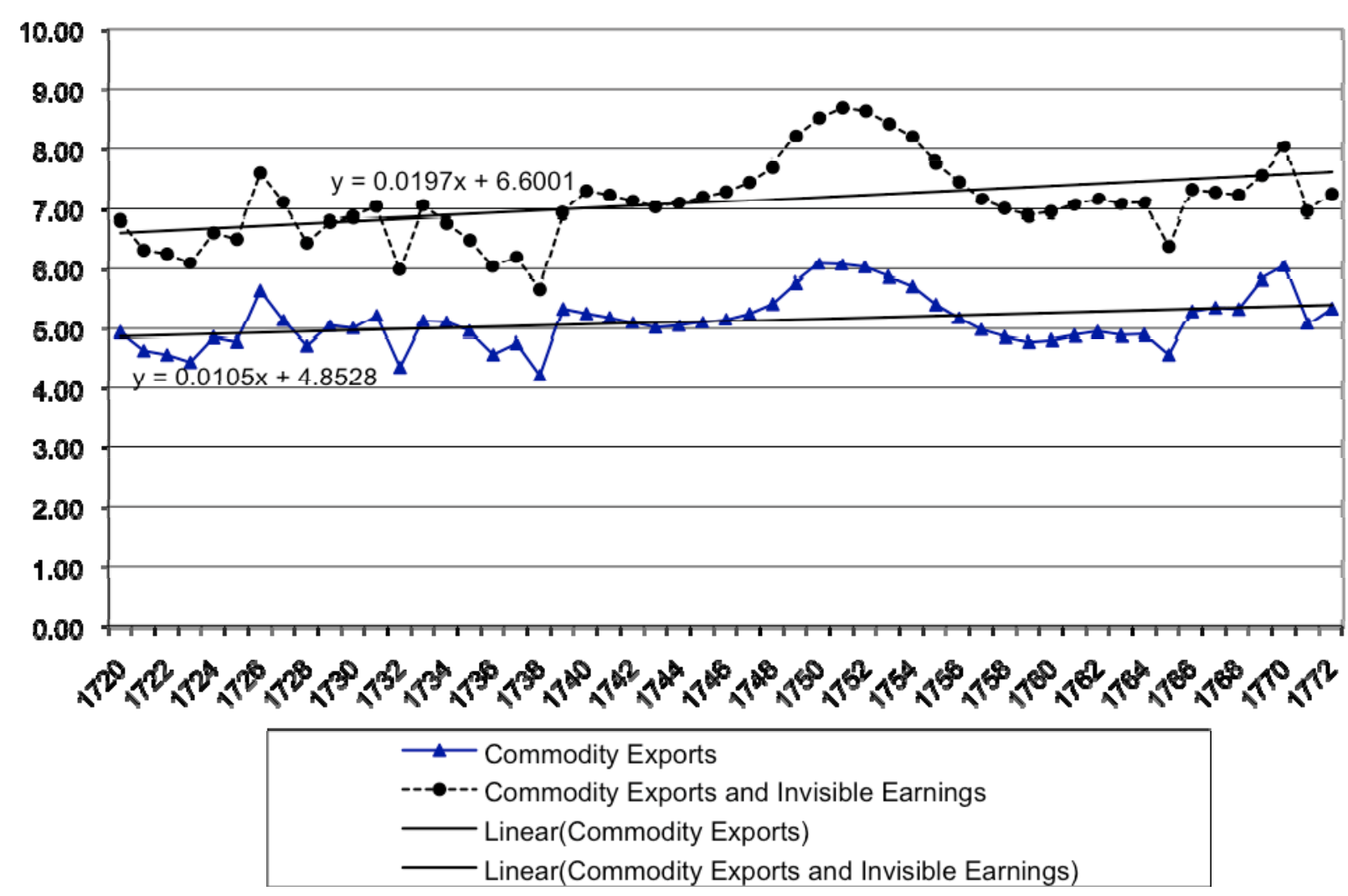

Notes and sources: Population is the sum of population in New York, New Jersey, Pennsylvania, and Delaware. Carter et al (2006, series Eg 9-12), linearly interpolated between observations. Commodity exports and invisible earnings are based on authors' calculations as described in the text and the Appendix. 
Figure 3

Terms of Trade for the Middle Colonies, 1720-1775

$(1768-1772=100)$

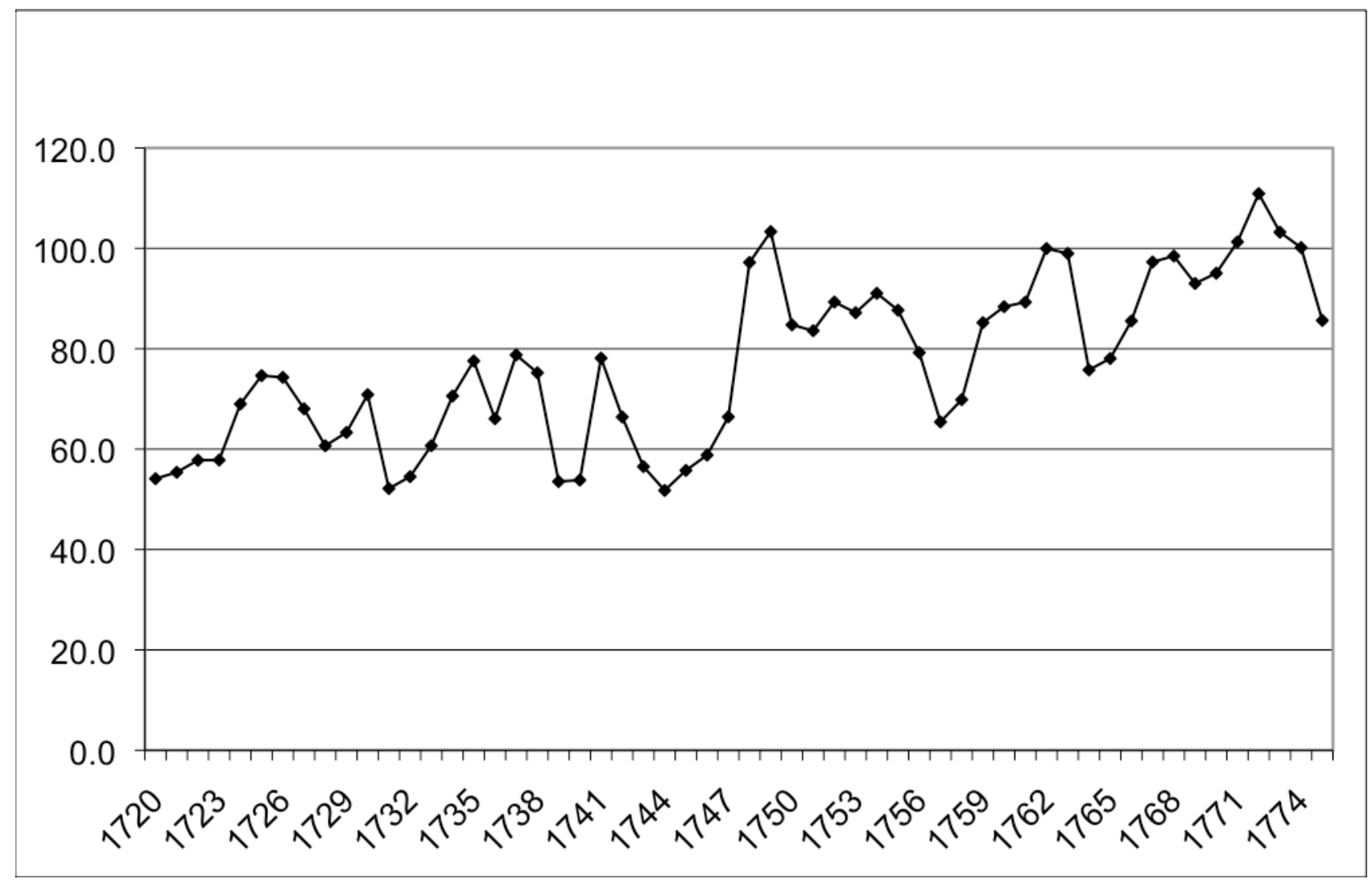

Notes and sources: Import prices are an average of the three series reported in Schumpeter (1938); Export prices are a weighted average (weights in parentheses) of flour (.87), wheat (.10), and pork (.03). All price data from McCusker (2006. Eg 252, 257, 259). See Appendix for further details. 


\section{References}

Clowse, Converse (1971). Economic Beginnings in Colonial South Carolina. Columbia: University of South Carolina Press.

Coclanis, Peter (1989). The Shadow of a Dream Economic life and death in the South Carolina low country, 1670-1920. New York: Cambridge University Press.

Cole, Arthur Harrison (1938). Wholesale Commodity Prices in the United States, 1700-1861. Cambridge: Harvard University Press.

Crowther, Simeon (1973). “The Shipbuilding Output of the Delaware Valley, 1722-1776," Proceedings of the American Philosophical Society, vol. 117, No. 2 (April 10, 1973), 90-104.

Egnal, Marc (1975). "The Economic Develoment of the Thirteen Colonies, 1720-1775." William and Mary Quarterly. $3^{\text {rd }}$ series, 32, 191-222.

Egnal, Marc (1998). New World Economies: The Groth of the Thirteen Colonies and Early Canada. New York and Oxford: Oxford University Press.

Harrington, Virginia (1935). The New York Merchant on the Eve of the Revolution. New York: Columbia University Press.

Jensen, Arthur L. (1963). The Maritime Commerce of Colonial Philadelphia. Department of History, Universit of Wisconsin. Madison: State Historical Society of Wisconsin.

Klopfer, Helen Louise (1936) “Statistics of Foreign Trade of Philadelphia, 1700-1860.” Ph.D. diss. University of Pennsylvania.

Lemon, James (1972). The Best Poor Man's Country (Baltimore).

Lydon, James(1967). “Philadelphia’s Commercial Expansion, 1720-1739.” Pennsylvania Magazine of History and Biography 91, pp. 401-19. 
Mancall, Peter C. (1991). Valley of Opportunity: Economic Culture along the Upper Susquehanna, 1700-1800 (Ithaca).

Mancall, Peter C. ed. (1996). Land of Rivers: America in Word and Image (Ithaca).

Mancall, Peter C. and Thomas Weiss (1999). "Was Economic Growth Likely in Colonial British North America?” Journal of Economic History 59, no. 1 (March), 17-40.

Mancall, Peter C., Joshua L. Rosenbloom and Thomas Weiss (2008). "Exports and the Economy of the Lower South Region, 1720-1772." Research in Economic History, $25,1-68$.

Matson, Cathy D. (1998). Merchants \& Empire: Trading in Colonial New York. Baltimore: Johns Hopkins University Press.

McCusker, John J. (1972). "Sources of Investment Capital in the Colonial Philadelphia Shipping Industry.” Journal of Economic History 32, no. 1 (Mar.), 146-57.

McCusker, John J. (2006). “Colonial Statistics.” In Carter, Susan B. et al, eds. (2006). Historical Statistics of the United States: Earliest Times to the Present (Cambridge University Press), vol. 5.

McCusker, John J. and Russell R. Menard (1984). The Economy of British America, 16071789: Needs and Opportunities for Study. Institute of Early American History and Culture. Chapel Hill and London: University of North Carolina Press.

Nash, R. C. (1992). "South Carolina and the Atlantic Economy in the Late Seventeenth and Eighteenth Centuries," Economic History Review 45.

North, Douglass C. (1961). "Early National Income Estimates of the U.S.," Economic Development and Cultural Change, 1961, vol. 9, part II. 
Price, Jacob M. (1984). “The Transatlantic Economy.” In Jack P. Greene and J.R. Pole, eds. Colonial British America: Essays in the New History of the Early Modern Era. Baltimore and London: Johns Hopkins University Press, 18-42.

Ratner, Sidney, James H. Soltow and Richard Sylla (1993). The Evolution of the American Economy: Growth, Welfare and Decision Making, $2^{\text {nd }}$ ed. New York: MacMillan. Schumpeter, Elizabeth Boody (1938). "English Prices and Public Finance, 1660-1822.” Review of Economic Statistics 20, no. 1, (Feb.), 21-37.

Shepherd, James (1969). “Commodity Exports from the British North American Colonies to Overseas Areas, 1768-1772: Magnitude and Patterns of Trade.” Purdue University, Krannert Graduate School of Industrial Organization. Paper no. 258.

Shepherd, James F. and Gary M. Walton, (1969). “Estimates of 'Invisible' Earnings in the Balances of Payments of the British North American Colonies, 1768-1772." Journal of Economic History 29, no. 2 (June), 230-63.

Shepherd, James F. and Gary M. Walton (1972). Shipping, Maritime Trade, and the Economic Development of Colonial North America. Cambridge: Cambridge University Press.

Shepherd, James F. and Samuel H. Williamson (1972). "The Coastal Trade of the British North American Colonies, 1768-1772." Journal of Economic History 32, no. 4 (Dec.), 783-810.

Smith, Daniel Scott (1980). “A Malthusian-Frontier Interpretation of United States Demographic History before c. 1815." In Urbanization in the Americas: The Background in Comparative Perspective, eds. Woodrow Borah, Jorge Hardoy and Gilbert A. Stelter. Ottawa. 
Alan Taylor (1996) William Cooper's Town: Power and Persuasion on the Frontier of the Early American Republic (New York).

Walton, Gary (1968). "New Evidence of Colonial Commerce," the Journal of Economic History, Vol. 28, No. 3, pp. 363-89 
